\title{
Working
}

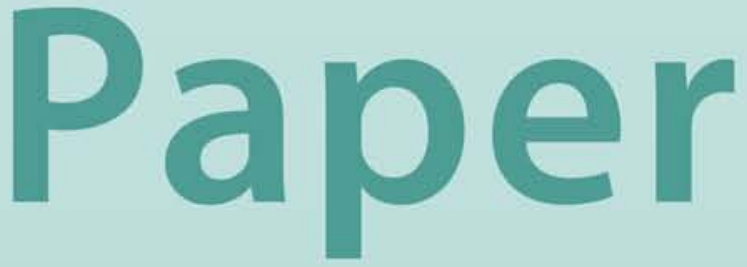




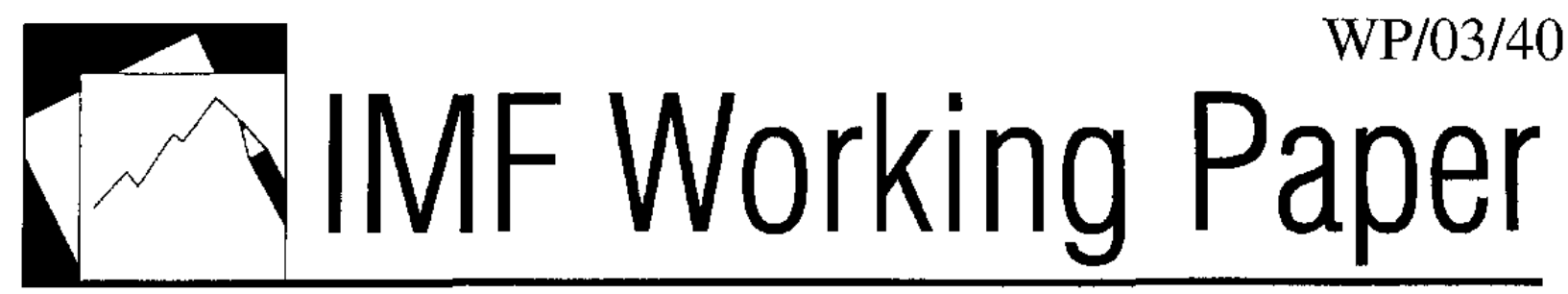

Foreign Aid and Consumption Smoothing: Evidence from Global Food Aid

Sanjeev Gupta, Benedict Clements, and Erwin R. Tiongson 


\title{
IMF Working Paper
}

Fiscal Affairs Department

\section{Foreign Aid and Consumption Smoothing: Evidence from Global Food Aid ${ }^{1}$}

\author{
Prepared by Sanjeev Gupta, Benedict Clements, and Erwin R. Tiongson \\ February 2003
}

\begin{abstract}
The views expressed in this Working Paper are those of the author(s) and do not necessarily represent those of the IMF or IMF policy. Working Papers describe research in progress by the author(s) and are published to elicit comments and to further debate.
\end{abstract}

Global food aid is considered a critical consumption smoothing mechanism in many countries. However, its record of stabilizing consumption has been mixed. This paper examines the cyclical properties of food aid with respect to food availability in recipient countries, with a view to assessing its impact on consumption in some 150 developing countries and transition economies, covering 1970 to 2000 . The results show that global food aid has been allocated to countries most in need. Food aid has also been countercyclical within countries with the greatest need. However, for most countries, food aid is not countercyclical. The amount of food aid provided is also insufficient to mitigate contemporaneous shortfalls in consumption. The results are robust to various specifications and filtering techniques and have important implications for macroeconomic and fiscal management.

JEL Classification Numbers: E320, F350, Q180

Keywords: Food aid, foreign aid, counterpart funds, consumption smoothing

Authors’ E-Mail Addresses: sgupta@imf.org, bclements@imf.org, etiongson@imf.org

\footnotetext{
${ }^{1}$ We thank Abbassian Abdolreza, Rina Bhattacharya, Aleš Buliř, Chris Barrett, Paul Cashin, Bikas Joshi, Menachem Katz, Noureddine Krichene, Wojciech Maliszewski, Srobona Mitra, Paulo Neuhaus, Michel A. Robe, Stéphane Pallage, Tobias Roy, Ratna Sahay, Shahla Shapouri, George Simon, Thierry Tressel, Luis Valdivieso, and Mario Zejan for helpful discussions and comments on an earlier draft. George Simon and Giampiero Lucarini (WFP) generously provided data on food aid.
} 


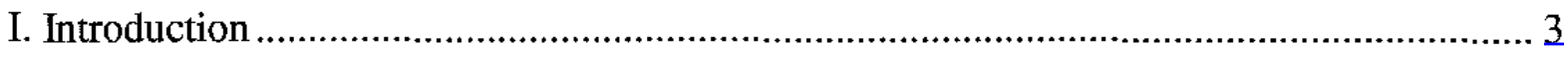

II. Literature Review ............................................................................................. 4

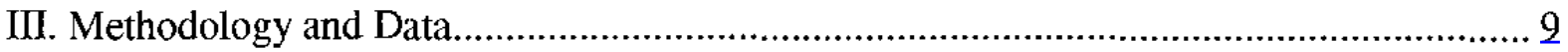

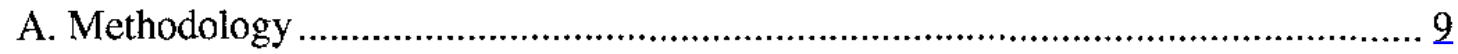

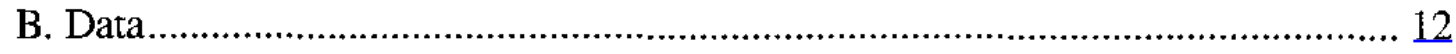

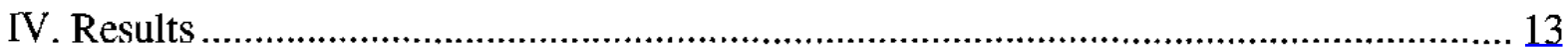

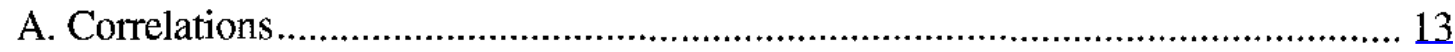

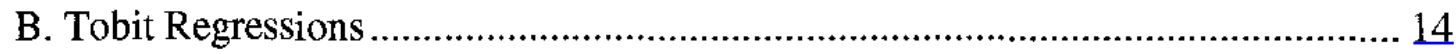

V. Discussion and Policy Implications ............................................................. 19

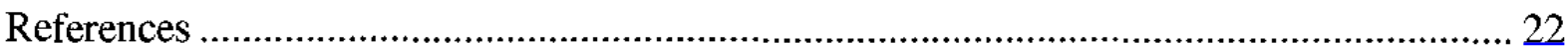

\section{Tables}

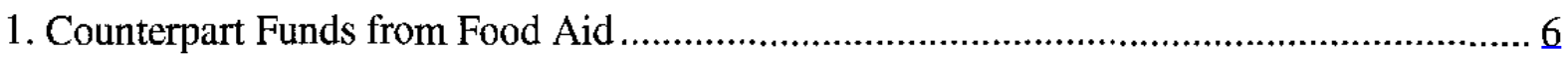

2. Cyclical Properties of Food Aid .......................................................................... 13

3. Baseline Tobit Regression Results: Linear Detrending ........................................... 14

4. Modified Tobit Regression Results: Linear Detrending ............................................ 15

5. Tobit Regression Results: Other Detrending Methods ............................................ 16

6. Modified Tobit Regression Results: Food Aid Flows Over Time ............................... 17

7. Tobit Regression Results: Fiscal Variables ......................................................... 18

8. Tobit Regression Results: Food Aid Sales and Fiscal Variables, 1987-2000................. 19

Appendix Table

9. Countries and Areas Included in the Sample........................................................ 21 


\section{INTRODUCTION}

The debate on aid effectiveness has largely focused on the impact of aggregate "development assistance" on economic growth or economic development more broadly (e.g., Easterly (2001), World Bank (1998)). As a result, relatively little attention has been paid to how well certain components of foreign aid achieve their stated objectives, such as disaster relief, humanitarian assistance, and food aid. In this paper, we focus on one particularly important component of foreign aid - food aid - and evaluate whether it helps stabilize consumption in recipient countries, and whether it has been targeted to those countries most in need.

Recent developments in Africa underscore the importance of food aid in smoothing consumption. The international community has called for increased food aid to meet shortfalls in domestic food supply. Some 13 million people are estimated to have been affected in six countries: Lesotho, Malawi, Mozambique, Swaziland, Zambia, and Zimbabwe. ${ }^{2}$ Shortfalls in food supply, together with the AIDS epidemic, are likely to have long-term implications for the region's malnutrition rates and susceptibility to disease. The WHO (2002) identifies childhood and maternal undernutrition as major health risks in developing countries. In some regions undernutrition prevalence is as high as 51 percent. It is also estimated that some 27 percent of children under five years of age worldwide are underweight.

A comprehensive evaluation of the effectiveness of global food aid in smoothing consumption in developing and transition economies has yet to be undertaken. While a number of studies have assessed the contribution of individual food aid programs (Clay and others (1996), Barrett (2001), Barrett and Heisey (2002)), a single program perspective can be misleading when assessing a country's food aid vis-à-vis country needs, as food aid is typically provided by a number of donors. Other studies, using broader measures of food aid, focus on selected regions. A more comprehensive evaluation would assess global food aid flows into all recipient countries.

Aid inflows (including food aid) affect government revenues and economic activity. This is the case when aid flows through the budget and if part or all of the commodity aid is sold in local markets. Wide variations in the receipt of commodity aid can thus lead to volatility in both government revenues and economic activity and make fiscal management more problematic. This paper also seeks to shed light on this issue by empirically assessing whether the timing of food aid has contributed to the volatility of government revenues and economic activity in recipient countries.

The paper is structured as follows: Section II reviews the literature on aggregate foreign aid, food aid, and consumption smoothing. Section III presents the empirical framework and the data sources. Section IV reports the empirical results and Section V concludes.

\footnotetext{
${ }^{2}$ Estimates indicate that the current shortfall in cereal crops in Africa could amount to 3 million tons, equivalent to about $\$ 750$ million (Price (2002)).
} 


\section{LITERATURE REVIEW}

The effectiveness of aid has been under scrutiny. A large number of papers have documented the dominant role played by strategic and political considerations in the allocation of foreign aid, rather than the needs and policy performance of the recipient economies (see, for example, World Bank (1998) and Alesina and Dollar (2000)). In particular, holding other factors constant, foreign aid is weakly correlated with the per capita income of the recipient government. ${ }^{3}$

A number of recent papers have also documented a pattern of aid volatility and aid procyclicality with respect to output and fiscal revenues. For example, Gemmell and McGillivray (1998) find that aid is more volatile than revenue and that aid tends to rise when economic activity is expanding. ${ }^{4}$ In a vast majority of African countries, aid flows have been found to be highly volatile and overwhelmingly procyclical (Pallage and Robe (2001)). Among non-African recipients, there is a similar but less pronounced pattern of aid procyclicality.

The procyclicality of foreign aid has important economic consequences. For example, aid volatility increases uncertainty regarding inflows into the budget and complicates the formulation and execution of the budget, particularly in a medium-term context (Bulír and Hamann (2001)). In addition, the procyclicality of aid implies that aid flows cannot stabilize fluctuations in consumption; direct (humanitarian) intervention does not take place at the time it is needed most. Previous research indicates that welfare costs from consumption volatility can be quite large. In particular, the welfare gain from mitigating volatility may exceed the gain from higher economic growth in many poor countries (Pallage and Robe (2002)).

Food aid is considered the main international safety net for many low-income countries. ${ }^{5}$ Food aid is meant to offset food shortages due to shortfalls in domestic food production or the volatility of global commodity prices. Such aid is provided both bilaterally and multilaterally, and is often drawn from food surpluses of donor countries. It is usually made available for free or on highly concessional terms. Food accounts for at least 60 percent of total expenditures among poor households in some countries, and, as such, food availability is critical for food security (van Holst Pellekaan (2001)). For addressing emergencies, the

\footnotetext{
3 Worse, the empirical evidence indicates that, by some measures, more foreign aid has flowed into more corrupt countries or countries with poor management of financial resources.

${ }^{4}$ Buliř and Hamann (2001) find that the correlation between aid and fiscal revenue is positive, though mostly insignificant.

${ }^{5}$ See, for example, Shapouri and Rosen (2001), WFP (2002), and Barrett (2002).
} 
IMF has a food financing facility. ${ }^{6}$ In a number of countries with PRGF-supported programs, food aid is a significant component of foreign financing (e.g., São Tomé and Príncipe) and covers domestic consumption shortfalls (e.g., Chad, Ethiopia, The Gambia, and Rwanda).

Counterpart funds generated by commodity aid including food aid provide critical budget support. Commodities provided as food aid are either distributed directly to households, sometimes as part of social assistance programs, or sold in domestic markets by the government or by government agencies at below-market prices. The sale of food aid generates counterpart funds in local currency, thus providing general support for the budget. In São Tomé and Príncipe, for example, counterpart funds from food aid finance social services, such as schooling and health care.

The size of counterpart funds is substantial in many recipient countries (Colding and Pinstrup-Andersen (2000)). The share of program food aid in global food aid (or food aid delivered mainly on a bilateral basis for sale on local markets) provides an approximation of the relative importance of counterpart funds. Until 1990, about 60 percent of total food aid was program food aid, with the rest divided equally between project and emergency aid. Between 1996 and 2001, the share of program food aid fell to 40 percent of global food aid. Counterpart funds (from food aid, commodity aid, and project aid) accounted for about 30 percent of government revenue in Mozambique in the early 1990s (Riley (1992)). In Albania, counterpart funds from food aid sales amounted to 5 percent of government expenditure and 3 percent of GDP during this same period. In Georgia, revenues from food aid sales amounted to about 15 percent of total expenditures in the mid-1990s (UNDP (1996)). Summary data on counterpart funds for selected countries are provided in Table 1.

Fluctuations in food aid can have important macroeconomic consequences. As counterpart funds generated by food aid can be an important source of government revenue, variations in food aid have implications for macroeconomic management. In particular, the timing of food aid and its sale could be viewed as an "automatic stabilizer" for the economy; when food output in a country falls, government revenues decline and spending increases. Monetization of food aid flows under these circumstances stabilizes flows to the budget in addition to shielding food consumption levels in the country. Furthermore, food aid (including commodities distributed directly to households) is critical for alleviating spending pressures on the budget to offset the adverse consequences of food shortages. ${ }^{7}$

\footnotetext{
${ }^{6}$ The IMF provides temporary food financing under the Compensatory Financing Facility (CFF). Countries facing temporary difficulties from higher cereal import costs may seek support from the CFF, formerly the Compensatory and Contingent Financing Facility (CCFF).

${ }^{7}$ It is difficult to quantify the value of nonmonetized food aid flows for the budget. In effect, these flows are a type of implicit subsidy provided by the government. In Georgia, for example, the bulk of food aid was passed on to consumers through sales on domestic markets in the early 1990s. Because of price controls, the government provided an implicit subsidy on the sale of bread by state-owned outlets. This subsidy amounted to as much as 7 percent of GDP in 1993 (Wang (1999)).
} 
Table 1. Counterpart Funds from Food Aid

(In units as indicated; selected countries and years)

\begin{tabular}{llccccc}
\hline & & & \multicolumn{5}{c}{ In percent of } \\
\cline { 5 - 7 } & $\begin{array}{c}\text { Level } \\
\text { of Government }\end{array}$ & Year & Grants & $\begin{array}{c}\text { Total Revenue } \\
\text { and Grants }\end{array}$ & $\begin{array}{c}\text { Total } \\
\text { Expenditure }\end{array}$ & GDP \\
\hline Albania & Central & 1991 & 100.0 & 8.9 & 4.5 & 2.9 \\
Cape Verde & Central & 2001 & 36.7 & 5.8 & 4.9 & 1.5 \\
Ethiopia $^{{ }^{3}}$ & General & $2000 / 01$ & 37.2 & 7.6 & 6.4 & 1.9 \\
Georgia $_{\text {Kenya }}$ & Central & 1995 & 94.5 & 24.0 & 15.0 & 1.8 \\
Mozambique & Central & 2000 & 51.7 & 5.8 & 5.2 & 1.5 \\
Pakistan & Central & 1990 & $\ldots$ & $\ldots$ & 30.0 & 15.0 \\
& Central & $1998 / 99$ & 92.2 & 3.4 & 2.5 & 0.4 \\
\hline
\end{tabular}

Sources: Riley (1992); UNDP (1996); and IMF staff estimates.

${ }^{1}$ Proxied by an expenditure item on food and emergency aid, financed by foreign grants.

Little is known about the cyclical properties of global food aid despite its relevance for economic activity and fiscal policy in recipient countries. There are three sources of evidence on the cyclical properties of global food aid, all of which provide incomplete information: (i) case studies, (ii) time-series studies, and (iii) cross-country econometric evidence. With respect to the first source, a handful of case studies of individual food aid programs suggest that food aid is not effective in addressing transitory food insecurity. For example, an evaluation of the European Union food program found that its effectiveness was "frequently reduced by slow implementation, inappropriate commodities, and lack of coordination on commitments and logistics" (Clay and others (1996)).

Time-series studies have examined the relationship between global food aid and fluctuations in world commodity prices (see, for example, Benson (2000) and Taylor and Byerlee (1991)). All these studies confirm a negative relationship between food aid and world prices, thereby providing some evidence that food aid falls as commercial imports become more expensive. Therefore, food aid fails to mitigate transitory food insecurity. However, these studies do not provide information on the relationship between food aid and cyclical fluctuations in aggregate domestic food availability by country.

With respect to cross-country econometric studies, the literature has examined the cyclicality of either individual food aid programs alone or multilateral food aid programs for small 
samples of countries. ${ }^{8}$ The empirical findings are mixed. Konandreas (1987) finds a negative relationship between aid flows from individual donors and deviations of cereal production in recipient countries from trend levels of production in the rest of the world ${ }^{9}$; this suggests that food aid is countercyclical. In contrast, Barrett (2001) assesses U.S. food aid and fails to find any significant correlation between food aid flows and fluctuations in domestic per capita food availability. In fact, he provides some evidence that food aid flows may be procyclical, contrary to expectations. Likewise, Mellor and Pandya-Lorch (1992) show that cumulative food aid has been destabilizing with respect to food availability in Senegal, Kenya, and, to some extent, in Tanzania. For a sample of 12 sub-Saharan African countries, Trueblood and others (2001) note that food aid has a generally negligible impact on stabilizing food supplies, as measured by reductions in standard deviations of food supplies over the 1970-95 period.

On the other hand, Lavy (1992) finds that global emergency food aid has been responsive to shortfalls in cereal production in sub-Saharan countries. He estimates that over a period of four years, a one-ton drop in production is matched by the eventual delivery of up to 0.8 tons of cereal and dairy products. Similarly, Barrett and Heisey (2002) find that multilateral food aid from the World Food Programme (WFP), which amounts to a third of total food aid, is countercyclical. However, Gabbert and Weikard (2001) find no clear indication that multilateral food aid performs better than four selected bilateral food aid programs in targeting transfers toward recipient countries' needs, as measured by levels of undernourishment. They suggest that all donors need to improve their allocation of aid and adopt a more "needs-oriented" approach.

There is mixed evidence on how well food aid is targeted to countries with the greatest need. Konandreas (1987) shows a negative correlation between food aid shipments and the worldwide level of production. ${ }^{10}$ Shapouri and Missiaen (1990), using 1975 and 1985 data on bilateral and multilateral aid flows, find that food aid allocation is based not only on donors' trade and political interests but on recipients' economic conditions as well, as measured by food production growth, food self-sufficiency, and other variables. In contrast, Diven (2001) estimates that over a 35-year period, U.S. food aid is not significantly correlated with food

\footnotetext{
${ }^{8}$ An important exception is a study of the cyclicality of cumulative food aid from several major donors by Shapouri and Rosen (2001), for a fairly large sample of countries. However, instead of looking at cumulative food aid that flows into each recipient economy, they compare the sum of consumption shortfalls (or deviations from an 18-year trend) for 62 low-income countries with the sum of food aid received by these countries, between 1981 and 1999. They find that food aid covers a significant share of the consumption shortfall as a whole. However, because food aid has fallen in absolute terms over time, the share of the consumption shortfall covered by food aid has also decreased.

${ }^{9}$ The details of the regression results are not provided. This summary is based on the author's own description of the resuits.

${ }^{10}$ See previous footnote.
} 
production in recipient countries. Similarly, Barrett (2001) notes that the distribution of U.S. food aid is only weakly progressive (i.e., allocated to countries in greatest need). The results hold regardless of whether food aid covers program food aid alone or emergency food aid alone.

The literature on aggregate foreign aid offers some insight into why food aid may fail to stabilize consumption. In the case of aggregate aid, studies have determined the following: First, as previously pointed out, political considerations motivate aid allocation. Second, aid is adjusted to donor countries' own business cycle. If a positive correlation exists between business cycles of industrial countries and developing countries, then aid is disbursed procyclically. Pallage and Robe (2001) find this to be true in general, though this is not the case for most sub-Saharan African recipients. Third, aid is fungible and displaces recipient countries' own resources (World Bank (1998)).

With respect to food aid, there exists a substantial literature on the political and nonhumanitarian determinants of food aid policy. ${ }^{11}$ For example, food aid is often drawn from donor surpluses and may, therefore, be adjusted to donors' business cycles (Diven (2001)). There is also a voluminous literature on whether food aid provides additional resources or simply displaces commercial imports (Maxwell and Singer (1979), Lavy (1990)).

The specific institutional characteristics of food aid may also explain its cyclical properties. For example, food aid is budgeted in monetary terms, rather than in volume. This implies that when commodity prices rise, both food aid and commercial imports fall. The model developed by Taylor and Byerlee (1991) underscores this point.

A number of important issues remain unresolved in the empirical literature on food aid. First, because food aid is typically provided by a number of donors, evaluating the performance of individual programs in responding to food shortages can be misleading. An evaluation of the performance of global food aid would be more appropriate. Second, the cyclical properties of food aid with respect to revenues and the overall deficit have not been examined. Because food aid can provide additional revenue and because food shortages can be symptoms of a more fundamental economic downturn, the magnitude and direction of co-movements between food aid and measures of economic activity provide useful information. Third, recent research has found that the results of business cycle studies are sensitive to the choice of filter (see, for example, Canova (1999)). This implies that the robustness of results from empirical studies of food aid should be tested against various filtering techniques and model specifications. Fourth, the literature on food aid has noted a change in the composition of food aid toward emergency aid, raising the question of whether its cyclical properties have also changed. Finally, while the literature has noted that foreign aid is not necessarily

\footnotetext{
${ }^{11}$ See, for example, Ball and Johnson (1996), Eggleston (1987), Shapouri and Missiaen (1990), and Diven (2001).
} 
progressive, the issue of whether this also applies to global food aid per se has yet to be settled. $^{12}$

\section{Methodology AND DATA}

\section{A. Methodology}

This paper employs two strategies for assessing the cyclical properties of foreign aid with respect to domestic food availability in recipient countries: (1) the calculation of correlation coefficients between food aid and domestic food availability detrended by the HodrickPrescott filter; and (2) a two-step Tobit regression of food aid on a measure of relative shortfalls in consumption and a measure of absolute shortfalls in consumption (see Barrett (2001)). As explained below, the second strategy also provides a test for the progressivity of food aid distribution.

\section{Hodrick-Prescott Filter}

First, following the literature (see, for example, Cooley (1995)), we measure business cycles as deviations from trend. We detrend nonconcessional food availability using the Hodrick and Prescott (1997) (HP) filter, which for a series $x$, extracts the growth component $x^{g}$ and the cyclical component $x^{c}=x-x^{3}$ by minimizing the following loss function:

$$
\sum_{i} x^{c^{2}}+\lambda \sum_{i}\left(\left(x_{t+1}^{g}-x_{t}^{g}\right)-\left(x_{t}^{g}-x_{i-1}^{g}\right)\right)^{2}
$$

where $\lambda$ is a weight that reflects the relative variance of growth and cyclical components. For annual data, $\lambda=100$ by convention. ${ }^{13}$ The logarithm of $x$ is used to calculate percentage deviations from trend. The correlations between global food aid and the cyclical component of domestic food availability are calculated contemporaneously, and with leads and lags up to two years. For comparison, we also calculate the correlations between food aid and the cyclical components of log per capita income as a measure of economic activity and a proxy for consumption shortfalls.

\section{Two-step estimation}

Beginning with Konandreas (1987), the empirical literature on food aid and consumption smoothing has examined how food aid flows respond to shortfalls in food availability by first

\footnotetext{
12 The impact of food aid on domestic food production has also attracted a great deal of attention (see Lavy (1990) and Lahiri and Raimondos (1996)). An assessment of this issue is beyond the scope of this paper.

${ }^{13}$ Given the uncertainty about the nature of business cycles in developing countries, we recognize that there could be a case for using different values of lambda to asses the robustness of the results. Instead, we opt to use alternative detrending techniques (as described below) as a robustness test. In addition, recent research indicates that traditional values for lambda are appropriate for most countries (Marcet and Ravn (2001)).
} 
measuring food availability in terms of deviations from a trend (Lavy, 1992; Mellor and Pandya-Lorch, 1992; Shapouri and Rosen, 2001), and then examining the statistical relationship between food aid and such deviations. We use the same two-step estimation procedure, but adopt the specification in Barrett (2001) and Barrett and Heisey (2002). Their method has the added feature of providing a measure of progressivity (that is, whether food aid flows are, on average, targeted toward countries with greater absolute shortfalls in food availability).

The first step requires estimating the growth rate in nonconcessional food availability (NA) using a logarithmic trend regression for each country in the sample:

$$
\ln \left(N A_{t}\right)=\alpha_{0 N}+\alpha_{1 N} \text { Year }+\varepsilon_{n t}
$$

where $\varepsilon_{n t}$ captures the deviations around the trend nonconcessional NA. NA is measured using the FAO data as the sum of domestic food production (PROD) plus total food imports (IM). ${ }^{14}$

The second step involves the regression of food aid per capita (FA) on $\varepsilon_{n t}$ and the level of NA. Because FA is a nonnegative variable often taking a value of zero, the relationship is estimated using a panel data Tobit specification:

$$
\begin{array}{ll}
\tilde{F} A_{i t}=\beta_{0}+\beta_{1} \varepsilon_{n i t}+\beta_{2} N A_{i t}+\sum_{r} \lambda_{r} D_{i r}+\sum_{t} \theta_{t} Y_{i t}+\omega_{i t} & \text { if } \mathrm{FA}_{\mathrm{it}}>0 \\
\tilde{F} A_{i t}=0 & \text { if } \mathrm{FA}_{\mathrm{it}}=0
\end{array}
$$

where $i$ is the index of the recipient country, $t$ is the year, and $r$ is region. ${ }^{15}$ In equation (3a), $\beta_{1}$ is a measure of the stabilization effect of food aid and $\beta_{2}$ is the measure of progressivity, controlling for fixed effects of regions and years (as captured by the dummy variables D and $\mathrm{Y}$ for regions and years, respectively). The method thus distinguishes relative shortfalls $\left(\varepsilon_{n t}\right)$ from absolute shortfalls $(N A)$ in food availability. In particular, $\beta_{1}<0$ indicates that global food aid is countercyclical, $\beta_{I}>0$ indicates that it is procyclical, and $\beta_{I}=0$ indicates that it is

\footnotetext{
${ }^{14}$ Where transport from food-surplus to food-deficit regions remains very costly or not at all possible (e,g., Ethiopia), this measure of domestic food availability may not be completely appropriate. That is, aggregate food availability may be sufficient, but significant shares of the population are suffering from food shortages.

15 Given our interest in assessing whether food aid responds to food needs across (as well as within) countries, country fixed effects are not included.
} 
acyclical. ${ }^{16}$ The sign of $\beta_{2}$, on the other hand, indicates whether food aid is progressive $\left(\beta_{2}>\right.$ 0 ) would indicate the progressivity of global food aid.

Barrett and Heisey (2002) note two possible sources of bias in the estimation of equations (3a) and (3b): (i) omitted variables bias, and (ii) endogeneity bias due to reverse causality between food aid $(F A)$ and food availability $(N A)$, through commercial imports $(I M=N A$ $P R O D)$.

Regarding (i), control for lagged food aid may be required because a number of studies note that food aid flows are persistent. In particular, Diven (2001) finds a strong incremental trend in food aid programming, where policymakers appear to use shipments from the previous year as starting point for marginal adjustments. Evidence from micro data confirms some spatial inertia in food aid allocations as well, which means that food aid allocation to certain regions persist (Clay and others (1999) and Jayne and others (2002)), for various reasons, including significant fixed costs in food aid operations.

With respect to (ii), food aid flows may have an effect, both lagged and contemporaneous, on commercial food imports by the recipient, as some imports are displaced by food aid. There is thus some reverse causality between food aid and food availability, via food imports.

Though an argument could be made that food aid flows may also depress production, there is no evidence that food aid $\left(F A_{i t}\right)$ has any contemporaneous effect on domestic food production $\left(P R O D_{i l}\right)$ (Barrett (2002)).

To correct for these biases, Barrett and Heisey (2002) suggest reestimating equations (3a) and ( $3 \mathrm{~b})$ as follows:

$$
\begin{array}{lr}
\tilde{F} A_{i t}=\varphi_{0}+\phi_{1} \varepsilon_{p i t}+\varphi_{2} P R O D_{i t}+\varphi_{3} F A_{i t-1}+\sum_{r} \sigma_{r} D_{i r}+\sum_{t} \omega_{t} Y_{i t}+\omega_{i t} & \text { if } \mathrm{FA}_{\mathrm{it}}>0 \\
\tilde{F} A_{i t}=0 & \text { if } \mathrm{FA}_{\mathrm{it}}=0
\end{array}
$$

where $\varepsilon_{p i t}$ is a measure of fluctuations in domestic food production as in equation (2), $F A_{i t-1}$ is lagged food aid, and $P R O D_{i t}$ is a measure of domestic food production per capita. $P R O D_{i t}$ may be treated as exogenous. The sign of $\varphi_{1}$ indicates the cyclical properties of global food aid.

\footnotetext{
${ }^{16}$ To the extent that there is substitution between food aid and other aid categories (thus increasing budget pressures during famine, for example), countercyclical food aid may still be inadequate to smoothen consumption. This issue is beyond the scope of the paper.
} 


\section{Modifications}

To test the robustness of the results to the choice of filters, we employ other filtering or detrending techniques in both procedures. In addition to the Hodrick-Prescott filter, we employ linear and quadratic detrending. In particular, we decompose a data series into a cyclical component and a linear function of time:

$$
x_{t}=\alpha+\beta * t+c_{t}
$$

This is similar to equation (2), where an OLS regression yields residuals $\left(\varepsilon_{t}\right)$ that are the cyclical component of the series $\left(c_{t}\right)$. The quadratic trend adds a second term to equation (5):

$$
x_{t}=\alpha+\beta * t+\gamma^{*} t^{2}+c_{t}
$$

We also use an approximation of the band-pass filter developed by Christiano and Fitzgerald (1999). This filters both high frequency "noise" and low frequency "trends," thus leaving fluctuations within a specified band at typical business cycle frequencies ( 1.5 to 8 years).

Using the new filtering procedures, one possible modification to the two-step method would be to estimate $\varepsilon_{n t}$ as deviations from a nonlinear trend $\left(\varepsilon_{n t}{ }^{N}\right)$, rather than from a linear time trend implied by equation (2). Equation (3a), for example, is then estimated as:

$$
\begin{aligned}
\widetilde{F} A_{t} & =\beta_{0}+\beta_{1}{\varepsilon_{n i t}}^{N}+\beta_{2} N A_{t}+\sum_{r} \lambda_{r} D_{i r}+\sum_{t} \theta_{t} Y_{i t}+\omega_{\text {it }} & & \text { if } \mathrm{FA}_{\mathrm{it}}>0 \\
\tilde{F} A_{t} & =0 & & \text { if } \mathrm{FA}_{\mathrm{it}}=0
\end{aligned}
$$

A test of the null hypothesis $\beta_{1}=0$ versus the alternate hypothesis $\beta_{I}<0$ is again a direct test of the procyclicality of global food aid. A similar procedure may be applied to equations ( $4 a$ ) and $(4 b)$.

\section{B. Data}

This paper uses comprehensive data on global food aid flows over thirty years, 1970-2000, covering some 150 recipient countries. The countries in the sample are listed in Appendix Table 1. Global food aid data are drawn from the WFP's Food Aid Flows (various issues) and the Food and Agriculture Organization's (FAO) FAOSTAT database. ${ }^{17}$ Data on population, domestic food production, and total food imports are from the FAOSTAT database. All food data are measured in volumes (metric tons). Following the literature, we proxy total food production, food imports, and global food aid using cereal volumes. This provides a comparable series without introducing aggregation problems. Cereals comprise

${ }^{17}$ The FAOSTAT database is available on-line at http://apps.fao.org. 
about 90 percent of global food aid. In addition, cereals account for most caloric and protein consumption in low-income countries, and are the largest source of macronutrients in developing countries (Barrett (2001)). All series are measured in per capita terms.

Data for GDP per capita, total government revenue (in percent of GDP), and overall deficit (in percent of GDP) are from the IMF's World Economic Outlook (WEO) database. The data generally cover the 1970-2000 period, though the time period may vary across countries.

\section{Results}

\section{A. Correlations}

Table 2 provides the summary information on the correlations between global food aid and cyclical fluctuations in nonconcessional food availability, by region. ${ }^{18}$ The estimates are based on food availability up to two periods in leads and lags, using linear and quadratic detrending as well as the band-pass and Hodrick Prescott filters (not reported). The results indicate that food aid is overwhelmingly acyclical across all regions. Some 100 out of the 150 countries in the sample have correlation coefficients less than zero. However, these are mostly within the intervals judged not significantly different from zero. At the most, only in 28 countries is food aid significantly countercyclical. The results are invariant to the choice of filter.

Table 2. Cyclical Properties of Food Aid

(Lnwcighted averages: comovement with domestic nonconcessional food availability)

\begin{tabular}{|c|c|c|c|c|c|c|c|c|c|c|c|}
\hline & \multirow[b]{2}{*}{$\begin{array}{c}\text { Sample } \\
\text { Size }\end{array}$} & \multicolumn{5}{|c|}{ Linear Detrending } & \multicolumn{5}{|c|}{ Quadratic Detrending } \\
\hline & & $\begin{array}{c}\text { Two-period } \\
\text { Lag }\end{array}$ & $\begin{array}{l}\text { Onc-period } \\
\text { I.ag }\end{array}$ & $\begin{array}{l}\text { Zero } \\
\text { I.ag }\end{array}$ & $\begin{array}{c}\text { One-period } \\
\text { Lead }\end{array}$ & $\begin{array}{c}\text { Two-period } \\
\text { Lead }\end{array}$ & $\begin{array}{c}\text { Two-period } \\
\text { Lag }\end{array}$ & $\begin{array}{c}\text { One-period } \\
\text { Lag }\end{array}$ & $\begin{array}{l}\text { Zero } \\
\text { Lag }\end{array}$ & $\begin{array}{l}\text { One-period } \\
\text { Lead1 }\end{array}$ & $\begin{array}{l}\text { Two-period } \\
\text { Lead }\end{array}$ \\
\hline Asia & 27.0 & -0.03 & -0.03 & -0.06 & 0.00 & -0.10 & 0.00 & -0.08 & -0.03 & 0.01 & -0.06 \\
\hline Middle East and North Africa & 16.0 & 0.06 & -0.04 & -0.04 & 0.10 & 0.10 & -0.05 & -0.05 & 0.00 & 0.08 & 0.02 \\
\hline Sub-Saharan Africa & 48.0 & 0.03 & 0.01 & -0.02 & 0.01 & -0.06 & -0.03 & 0.00 & 0.01 & 0.04 & 0.02 \\
\hline Transition & 24.0 & -0.08 & -0.06 & 0.00 & 0.07 & -0.06 & 0.03 & 0.20 & 0.10 & -0.21 & -0.26 \\
\hline Western Hemisphere & 33.0 & 0.06 & -0.06 & -0.11 & -0.03 & 0.01 & 0.03 & 0.01 & 0.08 & -0.06 & -0.06 \\
\hline Others & 5.0 & -0.09 & -0.13 & -0.09 & .0 .07 & -0.12 & -0.04 & -0.01 & -0.01 & 0.05 & 0.00 \\
\hline
\end{tabular}

Source: FAO database: WFP database: and authorg' calculations.

The correlations between food aid and the cyclical components of log per capita incomeas a measure of economic activity and proxy for consumption shortfalls-shows similar patterns (not reported).

${ }^{18}$ Country-level results (not reported) are available on request from the authors. 


\section{B. Tobit Regressions}

\section{Baseline regressions}

Table 3 presents the results of the Tobit regression of equations ( $3 a$ ) and ( $3 b$ ). For the sample as a whole, the results indicate that global food aid follows a significantly progressive distribution. This means that food aid has been responsive to absolute shortfalls in nonconcessional food availability across countries.

An equally interesting result is the progressivity of food aid flows among low-income countries (not reported). In fact, the relationship between per capita income and food aid is negative and significant, but the coefficient size is small $(-0.03)$. Food aid to these lowincome countries appears to have been triggered by absolute shortfalls in consumption. However, the preliminary results from Tobit regressions further confirm that, on average, food aid flows have not generally been responsive to fluctuations in food availability. In fact, there is evidence that food aid disbursements have been procyclical rather than countercyclical.

Table 3. Baseline Tobit Regression Results: Linear Detrending

(T-statistics in parentheses)

\begin{tabular}{lcccc}
\hline & $\begin{array}{c}\text { All } \\
\text { Countries }\end{array}$ & $\begin{array}{c}\text { All } \\
\text { Countries }\end{array}$ & $\begin{array}{c}\text { All } \\
\text { Countries }\end{array}$ & $\begin{array}{c}\text { All } \\
\text { Countries }\end{array}$ \\
\hline$\beta_{I}$ (cyclicality) & $0.0136^{* * *}$ & $0.0096^{* *}$ & $0.0118^{* * *}$ & $0.0079^{*}$ \\
& $(2.92)$ & $(2.03)$ & $(2.52)$ & $(1.66)$ \\
$\beta_{2}$ (progressivity) & $-0.0422^{* * *}$ & $-0.0241^{* * *}$ & $-0.0425^{* * * *}$ & $-0.0246^{* * * *}$ \\
& $(-8.53)$ & $(-3.69)$ & $(-8.61)$ & $(-3.78)$ \\
Regional dummies & & & & No \\
Year dummies & No & Yes & Yes & Yes \\
LR Statistic & No & No & 120.44 & 213.41 \\
P-value & 79.05 & 171.36 & 0.00 & 0.00 \\
Number of observations & 0.00 & 0.00 & 3,720 & 3,720 \\
& 3,720 & 3,720 & & \\
\hline
\end{tabular}

Source: See text.

$(* * *),(* *)$, and $\left(^{*}\right)$ denote significance at the 1,5 , and 10 percent levels, respectively.

Accounting for bias arising from the absence of lagged food aid and the endogeneity of commercial food imports, as noted above, lagged food aid and domestic production (PROD) (to proxy nonconcessional food availability (NA)) are added to the baseline regressions, following equations (4a) and (4b). The regression results in Table 4 confirm that for the sample as a whole, global food aid is generally progressive and responds to absolute gaps across countries. 
Table 4. Moditied Tobit Regression Results: Linear Detrending (T-statistics in parentheses)

\begin{tabular}{|c|c|c|c|c|c|c|}
\hline & $\begin{array}{c}\text { All } \\
\text { Countries }\end{array}$ & $\begin{array}{c}\text { All } \\
\text { Countries }\end{array}$ & $\begin{array}{c}\text { Alt } \\
\text { Countries }\end{array}$ & $\begin{array}{l}\text { Most } \\
\text { Food Insecure }\end{array}$ & $\begin{array}{c}\text { Low } \\
\text { Income= }\end{array}$ & $\begin{array}{c}\text { Sub-Saharan } \\
\text { Africa }\end{array}$ \\
\hline$\varphi_{\lambda}$ (cyclicality) & $\begin{array}{l}-0.0012 \\
(-0.49)\end{array}$ & $\begin{array}{l}-0.0029 \\
(-1.17)\end{array}$ & $\begin{array}{l}-0.0033 \\
(-1.28)\end{array}$ & $\begin{array}{l}-0.007 * * * \\
(-2.21)\end{array}$ & $\begin{array}{l}-0.0107^{* * *} \\
(-7.16)\end{array}$ & $\begin{array}{l}-0.004^{* * * *} \\
(3.10)\end{array}$ \\
\hline$\varphi_{2}$ (progressivity) & $\begin{array}{l}-0.0392^{* * * *} \\
(-8.05)\end{array}$ & $\begin{array}{l}-0.0192^{* * * * *} \\
(-3.22)\end{array}$ & $\begin{array}{l}-0.0195^{* * * * *} \\
(-3.28)\end{array}$ & $\begin{array}{l}0.017 \\
(1.04)\end{array}$ & $\begin{array}{l}-0.0084 * * \\
(-2.01)\end{array}$ & $\begin{array}{l}-0.021^{* * * *} \\
(-4.05)\end{array}$ \\
\hline Food aid (t-1) & $\begin{array}{l}0.3705^{* * * *} \\
(69.02)\end{array}$ & $\begin{array}{l}0.3779^{* * * * *} \\
(55.62)\end{array}$ & $\begin{array}{l}0.3765^{* * * *} \\
(53.07)\end{array}$ & $\begin{array}{l}0.66^{* * * * *} \\
(20.88)\end{array}$ & $\begin{array}{l}0.6684 * * * * \\
(25.26)\end{array}$ & $\begin{array}{l}0.89^{* * * *} \\
(65.47)\end{array}$ \\
\hline Regional dummies & No & Yes & Yes & Yes & Yes & No \\
\hline Year dummies & No & No & Yes & Yes & Yes & Yes \\
\hline LR Statistic & 460.24 & 527.95 & 568.42 & 471.45 & 659.78 & 1980.25 \\
\hline P-value & 0.00 & 0.00 & 0.00 & 0.00 & 0.00 & 0.00 \\
\hline Number of observations & 3,558 & 3,558 & 3,558 & 900 & 810 & 1.310 \\
\hline
\end{tabular}

Source: See text.

$\left({ }^{* * *}\right),(* *)$, and $\left({ }^{*}\right)$ denote significance at the 1,5 , and 10 percent levels, respectively.

${ }^{1}$ Bottom quartile of countries ranked by average nonconcessional food availability over the period 1970-2000.

${ }^{2}$ Bottom quartile of countries ranked by average per capita income over the period 1970-2000.

Furthermore, the sign of $\varphi_{1}$ suggests that food aid is countercyclical for the sample as a whole but insignificant. We run the modified Tobit regressions for selected subsamples: the food-insecure (defined as the bottom quartile of countries ranked by nonconcessional food availability) and low-income countries (defined as the bottom quartile of countries ranked by per capita income). The results suggest that for the most food-insecure and low-income countries, food aid has been disbursed countercyclically. We further test whether this holds for sub-Saharan Africa given the absence of correlation between business cycles in donor countries and sub-Saharan Africa. The results indicate that food aid is significantly progressive and countercyclical in Africa.

The results in Table 4 imply that food aid covers a minuscule amount of food needs. In particular, food aid covers only about 7 kilograms out of every contemporaneous metric ton shortfall in food-insecure countries. This confirms previous findings in the literature that food aid mitigates consumption shortfall in some countries, but it is far from sufficient to cover the entire consumption shortfall. ${ }^{19}$ For example, Shapouri and Trueblood (2002) argue

${ }^{19}$ Barrett and Heisey (2002) estimate that multilateral food aid covers only little more than two kilograms out of every one metric ton shortfall in food availability. Lavy's (1992) estimates imply that food aid covers about 5 kilograms of a contemporaneous metric ton shortfall. He suggests that over a period of three years, cumulative food aid covers about 45 percent of the shortfall, three years after the negative shock. While it is encouraging that food aid eventually covers a substantial amount of a consumption shortfall, there are significant humanitarian costs associated with the delay in disbursement. 
that the gap between food needs and food availability in many low-income countries is growing and that food aid on its own is an inadequate safety net. In addition, for the majority of countries that are moderately food insecure, food aid disbursement is not countercyclical.

Finally, the coefficient on lagged food aid $\left(\varphi_{3}\right)$ is relatively large across specifications and significant, confirming previous findings that there is persistence or inertia in food aid distributions.

\section{Other filters}

The regression results reported in Table 3 and Table 4 are based on the linear detrending technique. We reestimate equations (4a) and (4b) and substitute measures of transitory shortfalls in food availability using the quadratric trend, band pass filter, and the HodrickPrescott filter for the sample as a whole. The results are reported in Table 5. Food aid flows are significantly progressive across all specifications; this suggests that food aid has responded to absolute shortfalls in food availability. The signs of $\varphi_{1}$ suggest that food aid disbursement is countercyclical, but the coefficients are statistically insignificant. For selected subsamples - food-insecure and low-income countries--the results also suggest that across all filters, food aid has been disbursed countercyclically (not reported). For subSaharan African countries, food aid is significantly progressive and countercyclical. Thus, the results are comparable with those reported in Table 4 . The results are generally invariant to the choice of filter.

Table 5. Tobit Regression Results: Other Detrending Methods (t-statistics in parentheses)

\begin{tabular}{|c|c|c|c|c|c|c|}
\hline & \multicolumn{3}{|c|}{ Bascline Tobit } & \multicolumn{3}{|c|}{ Modified Tobit } \\
\hline & Quadratic & HP Filter & Band Pass & Quadratic & HP Filter & Band Pass \\
\hline \multirow[t]{2}{*}{$\beta$, or $\varphi_{1}$ (cyclicality) } & -0.0034 & -0.0024 & -0083 & $-0.005^{*}$ & -0.004 & -0.003 \\
\hline & $(-0.65)$ & $(-0.40)$ & $(-0.82)$ & $(-1,89)$ & $(-1.44)$ & $(-0.52)$ \\
\hline \multirow[t]{2}{*}{$\beta_{2}$ or $\varphi_{2}$ (progressivity) } & $-0.0205^{* * *}$ & $-0.0209 * * *$ & $-0.0208^{* * *}$ & $-0.019 * * *$ & $-0.021^{* * *}$ & $-0.022^{* * *}$ \\
\hline & $(\cdot 3.19)$ & $(-3.25)$ & $(-3.32)$ & $(-3.23)$ & $(-3.53)$ & $(-3.71)$ \\
\hline \multirow[t]{2}{*}{ Food aid (t-1) } & & & & $0.36^{\text {m+n }}$ & $0.36^{* * *}$ & $0.36^{* * *}$ \\
\hline & & & & $(52.76)$ & $(52.63)$ & $(52.36)$ \\
\hline Regional dummies & Yes & Ycs & Yes & Yes & Yes & Ycs \\
\hline Year dummics & Yes & Yes & Yes & Yes & Ycs & Yes \\
\hline LR Statistic & 211.06 & 210.81 & 211.31 & 570.65 & 566.10 & 551.26 \\
\hline P-value & 0.00 & 0.00 & 0.00 & 0.00 & 0.00 & 0.00 \\
\hline Number of obscrvations & 3,720 & 3,720 & 3,720 & 3,558 & 3,539 & 3,510 \\
\hline
\end{tabular}




\section{Food aid in the 1990s}

The literature on food aid notes two trends in the international provision of food aid. On the one hand, following the end of the Cold War and with shrinking surplus commodity stocks following agricultural market liberalization in donor countries, food aid flows have fallen. On the other hand, food aid is being increasingly targeted toward emergencies. In recent years, there has been an explicit donor policy to give higher priority to humanitarian crises.

This provides a basis for another testable hypothesis: have food aid flows become more countercyclical over time? To test changes over time, we divide the sample into 10-year periods. As indicated in Table 6, food aid is consistently progressive; if anything, there is some evidence that it has become more progressive over time. In contrast, the responsiveness of food aid flows to transitory shortfalls in consumption has varied over time. In terms of decades, it was significantly countercyclical over the 1980s. Contrary to expectations, food aid has not become countercyclical in the 1990s. The results hold for a linearly detrended measure of food availability and are robust to other measures of cyclical fluctuations.

Table 6. Modified Tobit Regression Results: Food Aid Flows Over Time

( $T$-statistics in parentheses; linear detrending)

\begin{tabular}{|c|c|c|c|c|c|}
\hline & \multicolumn{5}{|c|}{ Periods } \\
\hline & $1971-1980$ & $1981-1990$ & $1991-2000$ & $1971-1990$ & $1981-2000$ \\
\hline$\varphi_{I}$ (cyclicality) & $\begin{array}{c}-0.0002 \\
(-0.15)\end{array}$ & $\begin{array}{l}-0.0048^{* * * *} \\
(-2.67)\end{array}$ & $\begin{array}{r}0.0027 \\
(0.38)\end{array}$ & $\begin{array}{l}-0.0030^{* * * *} \\
(-2.66)\end{array}$ & $\begin{array}{l}-0.0027 \\
(-0.74)\end{array}$ \\
\hline$\varphi_{2}$ (progressivity) & $\begin{array}{l}-0.014^{* * *} \\
(-5.06)\end{array}$ & $\begin{array}{l}-0.0154^{* * * *} \\
(-4.18)\end{array}$ & $\begin{array}{l}-0.0369 * * * \\
(-2.98)\end{array}$ & $\begin{array}{l}-0.0157^{* * *} \\
(-6.5 \mathrm{j})\end{array}$ & $\begin{array}{l}-0.0433 * * * \\
(-6.31)\end{array}$ \\
\hline Food aid $(t-1)$ & $\begin{array}{l}0.8176^{* * *} \\
(43.61)\end{array}$ & $\begin{array}{l}0.9104^{* * * *} \\
(45.93)\end{array}$ & $\begin{array}{l}0.1436^{* * *} \\
(4.08)\end{array}$ & $\begin{array}{l}0.8818^{* * *} \\
(63.65)\end{array}$ & $\begin{array}{l}0.3155^{* * * *} \\
(53.45)\end{array}$ \\
\hline Regional dummies & No & No & No & No & No \\
\hline Year dummies & No & No & No & No & No \\
\hline LR Statistic & 1118.66 & 1222.36 & 26.56 & 2309.19 & 229.59 \\
\hline P-value & 0.00 & 0.00 & 0.00 & 0.00 & 0.00 \\
\hline Number of observations & 1,189 & 1,186 & 1,183 & 2,257 & 2,369 \\
\hline
\end{tabular}

Source: See text.

$\left(*^{* *}\right),(* *)$, and $\left(^{*}\right)$ denote significance at the 1,5 , and 10 percent levels, respectively.

\section{Food aid and fiscal variables}

Previous studies suggest that counterpart funds generated by monetized food aid account for a significant share of the government budget in some countries. Using the same econometric framework in equations (3) and (4), we now examine how food aid moves with relative and 
absolute revenue shortfalls. We use the Hodrick-Prescott filter to detrend the revenue series and estimate relative revenue shortfalls.

The results are provided in Table 7 . The countries that have the largest revenue shortfall or largest overall fiscal deficit receive proportionately more aid.

\begin{tabular}{|c|c|c|c|c|c|c|}
\hline & \multicolumn{2}{|c|}{ All Countries } & \multicolumn{2}{|c|}{ Aid-Dependent Countries' } & \multicolumn{2}{|c|}{ Low-Income Countries ${ }^{2}$} \\
\hline & Balance & Revenue & Balance & Revenue & Balance & Revenue \\
\hline \multirow[t]{2}{*}{$\varphi_{1}$ (cyclicality) } & $0.0002 *$ & 0.0001 & 0.0002 & 0.0001 & 0.0001 & 0.00003 \\
\hline & $(1.78)$ & $(1.30)$ & $(1.47)$ & $(1.24)$ & $(0.83)$ & $(0.92)$ \\
\hline \multirow[t]{2}{*}{$\varphi_{2}$ (progressivity) } & $-0.0002 * * *$ & $-0.00012 * * * * n$ & $-0.0003^{* * * *}$ & $-0.0001^{* * *}$ & $-0.0002 * *$ & 0.0001 \\
\hline & $(-5.13)$ & $(-3.20)$ & $(-3.88)$ & $(-2.41)$ & $(-2.03)$ & $(1.24)$ \\
\hline \multirow[t]{2}{*}{ Food aid (t-l) } & $0.83 * * * *$ & $0.85^{2 * *}$ & $0.82 * * *$ & 0.84 : & 0.67 ***: & $0.67 * * *$ \\
\hline & $(59.30)$ & $(60.84)$ & $(44.10)$ & $(45.20)$ & $19.93)$ & $(19.67)$ \\
\hline Regional dummies & Yes & Yes & Yes & Yes & Yes & Yes \\
\hline Year dummies & Yes & Yes & Yes & Yes & Yes & Yes \\
\hline LR Stalistic & 2378.71 & 2366.29 & 1349.58 & 1.340 .44 & 427.99 & 426.45 \\
\hline P-value & 0.00 & 0.00 & 0.00 & 0.00 & 0.00 & 0.00 \\
\hline Number of observations & 2,414 & 2,414 & 1,382 & 1,382 & 500 & 500 \\
\hline
\end{tabular}

Source: See text

$\left({ }^{* * *}\right),(* *)$, and $\left(^{*}\right)$ denote significance at the 1,5 , and 10 percent levels, respecively.

${ }^{\mathrm{l}}$ Botom quartile of countrics ranked by average aid per capita over the petiod 1970-2000.

${ }^{2}$ Bottom quartile of countries ranked by average per capita income over the period 1970-2000.

These results are based on aggregate food aid. Because counterpart funds are generated from sale of commodities provided through aid, a more accurate measure would be an analysis of the component that is sold in local markets. ${ }^{20}$ Data on the volume of food aid sold, by country, are available from WFP for 1988 onwards. They indicate that, on average, the share of sold food in aggregate food aid has fallen from about 45 percent to 30 percent.

Using these data and employing the same econometric framework utilized above, we examine the impact of food aid volume sold in local markets on relative and absolute revenue shortfalls and the overall budget deficit. The results are reported in Table 8 . They suggest that food aid has benefited countries with large overall deficits. ${ }^{21}$ The magnitude is much larger than reported in Table 7 using aggregate food aid. However, there is no measurable

${ }^{20}$ However, nonmonetized food aid is also critical for alleviating spending pressures on the budget. In this respect, aggregate food aid (rather than just the volume sold in local markets) may be a more accurate measure. See footnote 7 .

${ }^{21}$ It can be argued that fiscal balances are jointly determined with food aid flows, as recipient governments incur new expenses associated with food aid agreements. However, given the very small share of food needs covered by contemporaneous food aid, this is not likely to have an impact on the empirical results. 
association between food aid sold on local markets and revenue shortfall, whether in absolute or relative terms.

Table 8. Tobit Regression Results: Foud Aid Sides and Fiscal Variables, 1987-2000

(Hodrick.Prescott tilter; t-statisics in parentheses;

\begin{tabular}{|c|c|c|c|c|c|c|}
\hline & \multicolumn{2}{|c|}{ Nll Countries } & \multicolumn{2}{|c|}{ Must Food-Insecure ${ }^{1}$} & \multicolumn{2}{|c|}{ Ais-Dependent Counnries ${ }^{2}$} \\
\hline & Balance & Kevenuc & Balance & Rcvenue & Balance & Revenue \\
\hline \multirow[t]{2}{*}{$\varphi_{t}(\mathrm{cyclicality})$} & -0.044 & -10.166 & -0.07 & 0.05 & -0.26 & -0.48 \\
\hline & $(-0.27)$ & $\{-1.04)$ & $(-0.39 !$ & $(0.29)$ & $(-1) .67)$ & $(-1.14)$ \\
\hline \multirow[t]{2}{*}{$\varphi_{2}$ (progressi vity) } & $-0.18 *$ & 0.05 & $-1] .24: 5: 8$ & -0.02 & $-0.30^{*}$ & 0.24 \\
\hline & $(2.28)$ & 10.97 & $(-3.55)$ & $(-0.49)$ & $(1.87)$ & $(1.55)$ \\
\hline \multirow[t]{2}{*}{ Ford aid (t-1) } & $0.83^{* * *}$ & $0.83^{-k: k-k}$ & $0.68^{3 *: 5}$ & $0.841 * *$ & $0.76^{\text {:**** }}$ & $0.76^{\text {;: : : }}$ \\
\hline & $(31.20\rangle$ & $(30.71)$ & $(11.18)$ & $(15.72)$ & $(1.3 .54)$ & $(13.51)$ \\
\hline Regional dummies & Yes & Yes & Yes & Yes & Yes & Yes \\
\hline Ycar dummies & Yes & Yes & Yes & Yes & Yes & Yes \\
\hline 1.R Statistic & 721.23 & 715.62 & 194.60 & 180.35 & 212.31 & 209.24 \\
\hline P-value & 0.00 & $0.0(3)$ & 0.000 & 0.60 & 0.00 & 0.00 \\
\hline Number of observations & 940 & 9401 & $23 \mathrm{I}$ & 231 & 205 & 265 \\
\hline
\end{tabular}

Source: See text.

$\left({ }^{*}: * *\right),(* *)$, and $\left.t^{*}\right)$ dencte siggilicance at the 1,5 , and 10 percent fevels. respectively.

'Bottom quartile of countries ranked by average nonconcessional food availabilicy over the period 1970-2000.

${ }^{2}$ Botom quatile of countries ranked by average aid per capita over the period 1970-2000.

\section{Discussion and Policy IMPlications}

While global food aid is a critical safety net in many countries, its record in stabilizing consumption has been mixed. This has long-term implications for malnutrition rates, health status, and development prospects of the most food-insecure.

The empirical evidence examined in this paper suggests that global food aid has been allocated to where it is most needed. Based on data covering a large sample of recipient countries over the 1970-1999 period, the evidence suggests that countries with larger absolute shortfalls in food availability have received more aid. Food aid has also been countercyclical within countries with the greatest need. The results are robust to various specifications and filtering techniques.

Food aid has nonetheless fallen short of its objectives. For the sample of food-insecure countries for which food aid has been countercyclical, quantities have not been enough to stabilize consumption. For other recipient countries, food aid has not been significantly countercyclical. Thus, in these countries, food aid does not function as a social safety net. In addition, the responsiveness of food aid flows to transitory shortfalls in consumption has varied over time. In terms of decades, it was significantly countercyclical over the $1980 \mathrm{~s}$, but not significantly countercyclical over the $1990 \mathrm{~s}$. With respect to fiscal variables, food aid has benefited countries with large overall fiscal deficits. However, there is no measurable 
association between food aid sold on local markets and revenue shortfall, whether in absolute or relative terms.

The acyclicality of food aid has two implications for macroeconomic and fiscal management. First, to the extent that recipient governments rely on counterpart funds as a revenue source and food aid is not disbursed in a countercyclical manner, the instability of budgetary revenues is not alleviated. Second, shortfalls in food supply increase demands on the government budget for programs to shield the consumption of the population. In the absence of counterpart funds from food aid, the government will have to rely on domestic resources for funding such programs. Falling revenues and rising demand for budgetary programs are thus likely to complicate macroeconomic management for countries receiving food aid. In the circumstances, the "automatic stabilizer" benefits of countercyclical food are largely not met.

There is a case for increasing food aid and improving the timing of disbursements. The timing of food aid can be corrected by development of effective early warning systems (Bulír and Hamann (2001)) involving the international community. For example, Poverty Reduction Strategy Papers (PRSPs) may improve the design of programs supported by multilateral agencies as well as improve donor coordination for timely disbursement of humanitarian aid by incorporating strategies for food provision and distribution as well as agricultural development. Exchanges of information on food availability, requirements, and aid disbursements on a regular basis among donors and aid recipients would be a constructive step toward this end (Clay and others (1996)). 
Appendix Table 9. Countries and Areas Included in the Sample

\begin{tabular}{|c|c|c|}
\hline Asia & Cameroon & Estonia \\
\hline Bangladesh & Cape Verde & Georgia \\
\hline Bhutan & Central African Republic & Hungary \\
\hline Cambodia & Chad & Kazakhstan \\
\hline China & Comoros & Kyrgyz Republic \\
\hline Fiji & Congo, Dem. Rep. & Latvia \\
\hline India & Congo, Rep. & Lithuania \\
\hline Indonesia & Côte d'Ivoire & Macedonia, FYR \\
\hline Kiribati & Djibouti & Moldova \\
\hline Korea, Dem. People's Rep. & Equatorial Guinea & Mongolia \\
\hline Korea, Rep. & Eritrea & Poland \\
\hline Lao PDR & Ethiopia & Romania \\
\hline Malaysia & Gabon & Russian Federation \\
\hline Maldives & Gambia, The & Slovenia \\
\hline Myanmar & Ghana & Tajikistan \\
\hline Nepal & Guinea & Turkmenistan \\
\hline Pakistan & Guinea-Bissau & Ukraine \\
\hline Papua New Guinea & Kenya & Western Hemisphere \\
\hline Philippines & Lesotho & Antigua and Barbuda \\
\hline Samoa & Liberia & Barbados \\
\hline Singapore & Madagascar & Belize \\
\hline Solomon Islands & Malawi & Bolivia \\
\hline Sri Lanka & Mali & Brazil \\
\hline Thailand & Mauritania & Chile \\
\hline Timor-Leste & Mauritius & Colombia \\
\hline Tonga & Mozambique & Costa Rica \\
\hline Vanuatu & Namibia & Cuba \\
\hline Vietnam & Niger & Dominica \\
\hline Middle East and North Africa & Nigeria & Dominican Republic \\
\hline Afghanistan, I.S. of & Rwanda & Ecuador \\
\hline Cyprus & São Tomé and Príncipe & El Salvador \\
\hline Egypt, Arab Rep. & Senegal & French Guyana \\
\hline West Bank and Gaza Strip & Seychelles & Grenada \\
\hline Iran, Islamic Rep. & Sierra Leone & Guatemala \\
\hline Iraq & Somalia & Guyana \\
\hline Israel & South Africa & Haiti \\
\hline Jordan & Sudan & Honduras \\
\hline Lebanon & Swaziland & Jamaica \\
\hline Libya & Tanzania & Mexico \\
\hline Malta & Togo & Netherlands Antilles \\
\hline Morocco & Uganda & Nicaragua \\
\hline Syrian Arab Republic & Zambia & Panama \\
\hline Tunisia & Zimbabwe & Paraguay \\
\hline Turkey & Trunsition & Peru \\
\hline Yemen, Rep, of & Albania & St. Kitts and Nevis \\
\hline Sub-Saharan Africa & Armenia & St. Lucia \\
\hline Angola & Azerbaijan & St. Vincent and the Grenadines \\
\hline Benin & Belarus & Suriname \\
\hline Botswana & Bosnia and Herzegovina & Trinidad and Tobago \\
\hline Burkina Faso & Bulgaria & Uruguay \\
\hline Burundi & Croatia & Venezuela \\
\hline
\end{tabular}




\section{REFERENCES}

Alesina, Alberto, and David Dollar, 2000, "Who gives foreign aid to whom and why?" Journal of Economic Growth, Vol. 5, No. 1 (March), pp. 33-63.

Ball, Richard, and Christopher Johnson, 1996, "Political, economic, and humanitarian motivations for PL 480 food aid: Evidence from Africa," Economic Development and Cultural Change, Vol. 44 (April), pp. 515-37.

Barrett, C.B., 2002, "Food Security and Food Assistance Programs," in B.L. Gardner and G.C. Rausser, eds., Handbook of Agricultural Economics (Amsterdam: Elsevier Science).

— 1998, "Food Aid: Is It Development Assistance, Trade Promotion, Both or Neither?" American Journal of Agricultural Economics, Vol. 80, No. 3, pp. 566-71.

_ 2001a, "Does Food Aid Stabilize Food Availability?" Economic Development and Cultural Change, Vol. 49, No. 2, pp. 335-49.

— Fluctuating Needs?" Food Policy, forthcoming.

Benson, Charlotte, 2000, "The Food Aid Convention: An Effective Safety Net?" in E. Clay, and O. Stokke, eds., Food Aid and Human Security (London: Frank Cass), pp. $102-19$.

Bulír, Aleš, and A. Javier Hamann, 2001, "How Volatile and Unpredictable Are Aid Flows, and What Are the Policy Implications?" IMF Working Paper No. 01/167 (Washington: International Monetary Fund).

Canova, Fabio, 1999, "Does detrending matter for the determination of the reference cycle and the selection of turning points?" Economic Journal, Vol. 109 (January), pp. 126-50.

Christiano, Lawrence J., and Terry J. Fitzgerald, 1999, “The band pass filter,” NBER Working Paper No. 7257 (Cambridge: National Bureau of Economic Research).

Clay, Edward, Sanjay Dhiri, and Charlotte Benson, 1996, Joint Evaluation of European Union Programme Food Aid (London: Overseas Development Institute).

Clay, Daniel C., Daniel Molla, and Debebe Habtewold, 1999, "Food aid targeting in Ethiopia: A study of who needs it and who gets it," Food Policy, Vol. 24, No. 4, pp. 391-409. 
Colding, Bjørg, and Per Pinstrup-Andersen, 2000, "Foreign aid as an aid instrument: Past, present and future," in Foreign Aid and Development, F. Tarp and P. Hjertholm, eds. (London: Routledge).

Cooley, Thomas, ed., 1995, Frontiers of Business Cycle Research (Princeton, N.J.: Princeton University Press).

Diven, Polly J., 2001, "The domestic determinants of US food aid policy," Food Policy, Vol. 26, pp. 455-74.

Easterly, William, 2001, The Elusive Quest for Growth: Economists' Adventures and Misadventures in the Tropics (Cambridge: MIT Press).

Eggleston, Robert C., 1987, "Determinants of the Levels and Distribution of PL 480 Food Aid: 1955-79," World Development, Vol. 15, No. 6, pp. 797-808.

Gabbert, S., and H.-P. Weikard, 2000, "The Poor Performance of the Rich-Bilateral Versus Multilateral Food Aid Allocation," Quarterly Journal of International Agriculture, Vol. 39, No. 2, pp. 199-218.

Gemell, Norman, and Mark McGillivray, "Aid and Tax Instability and the Government Budget Constraint in Developing Countries," CREDIT Research Paper No. 98/1, Centre for Research in Economic Development and International Trade, University of Nottingham.

Hodrick, Robert, and Edward Prescott, 1997, "Postwar U.S. business cycles: an empirical investigation," Journal of Money, Credit and Banking, Vol. 29 (February), pp. 1-16.

Jayne, Thomas S., John Strauss, Takashi Yamano, and Daniel Molla, 2002, "Targeting of food aid in rural Ethiopia: chronic need or inertia?" Journal of Development Economics, Vol. 68, No. 2 (August), pp. 247-88.

Konandreas, Panos, 1987, "Responsiveness of food aid in cereals to fluctuations in supply in donor and recipient countries," in M. Bellamy and B. Greenshields, eds., Agriculture and Economic Instability (Brookfield: Gower Publishing Co. Ltd.), pp. 90-94.

Lahiri, Sajal, and Pascalis Raimondos, 1996, "Food Aid and Food Production: A Theoretical Analysis," in Trade and Development: Essays in Honor of Jagdish Bhagwati, V. N. Balasubramanyam and D. Greenaway, eds. (London: St. Martin's Press).

Lavy, Victor, 1990, "Does food aid depress food production?" World Bank Policy Research Working Paper Series No. 460 (Washington: World Bank).

_ 1992, "Alleviating Transitory Food Crises in Sub-Saharan Africa: International Altruism and Trade," The World Bank Economic Review, Vol. 6, No. 1, pp. 125-38. 
Marcet, Albert, and Morten O. Ravn, 2001, "The HP-Filter in Cross-Country Comparisons," Universitat Pompeu Fabra and London Business School (unpublished).

Maxwell, S. J., and H. W. Singer, 1979, "Food aid to developing countries: A survey," World Development, Vol. 7, pp. 225-47.

Mellor, John, and Rajul Pandya-Lorch, 1992, "Food Aid and Development in the MADIA Countries," in Aid to African Agrculture: Lessons from Two Decades of Donors' Experience, Uma Lele, ed. (Baltimore: Johns Hopkins University Press).

Pallage, Stéphane, and Michel A. Robe, 2001a, "Foreign Aid and the Business Cycle," Review of International Economics, Vol. 9, No. 4, pp. 636-67.

- 2002, "On the Welfare Cost of Economic Fluctuations in Developing Countries," International Economic Review, forthcoming.

Price, Elizabeth, 2002, "IMF, World Bank Urge More Food Aid for Southern Africa," Dow Jones Newswires, August 1.

Riley, Barry, 1992, "An analysis of the use of counterpart funds in Mozambique," IDS Bulletin Vol. 23, No. 2, pp. 41-45.

Shapouri, S., and M. Missiaen, 1990, "Food Aid: Motivation and Allocation Criteria," United States Department of Agriculture Economic Research Service Foreign Agricultural Economic Report No. 240.

Shapouri, Shahla, and Stacey Rosen, 2001, "Food Food Security and Food Aid Distribution," Issues in Food Security, Agricultural Information Bulletin No. 765-4 (April) (Washington: U.S. Department of Agriculture).

Shapouri, Shahla, and Michael Trueblood, 2002, "Trade liberalization, food security, and food safety nets for low-income countries," Paper presented at the Solagral and SFER (Société Française d'Economie Rurale) Seminar, "Does trade liberalisation contribute to the improvement of food security?" Paris (June).

Taylor, Daphne, and Derek Byerlee, 1991, "Food Aid and Food Security," Canadian Journal of Agricultural Economics Vol. 39, pp. 163-75.

Trueblood, Michael A., Shahla Shapouri, and Shida Henneberry, 2001, "Policy Options to Stabilize Food Supplied: A Case Study of Southern Africa," Agriculture Information Bulletin No. 764 (June) (Washington: U.S. Department of Agriculture).

United Nations (UN), 2001, "High level international intergovernmental consideration of financing for development," United Nations General Assembly A/55/1000 (June). 
UNDP, 1996, Human Development Report: Georgia (New York: United Nations Development Programme).

van Holst Pellekaan, 2001, "Food policy in Poverty Reduction Strategy Papers," World Bank Presentation (May).

Wang, Jian-Ye, 1999, "The Georgian Hyperinflation and Stabilization," IMF Working Paper No. 99/65 (Washington: International Monetary Fund).

World Bank, 1998, Assessing aid: what works, what doesn't, and why (New York: Oxford University Press).

World Food Programme, 2002, 2001 Food Aid Flows (Rome: World Food Programme).

World Health Organization, 2002, World Health Report (Geneva: WHO). 